\title{
A STUDY OF THE ECOLOGICAL PATTERNS OF FARMING- PASTORAL ZONES IN SEMI-ARID REGIONS: USING THE WEST LIAOHE RIVER PLAIN OF CHINA AS AN EXAMPLE
}

\author{
YAN, L.*-CHEN, M. J. - MA, J. \\ China Institute of Water Resources and Hydropower Research, Beijing, China \\ (phonelfax: +86-10-6878-5706) \\ *Corresponding author \\ e-mail: xiangyangyl@163.com; phone: +86-189-1164-0461 \\ (Received $12^{\text {th }}$ Feb 2018; accepted $17^{\text {th }}$ May 2018)
}

\begin{abstract}
The farming-pastoral zones in semi-arid regions of China are known to be typically ecologically vulnerable areas. It is required to research the agricultural and pastoral area ecological pattern that can guarantee ecological safety, and put forward the reasonable ratio for plough and grassland. This study selected the West Liaohe River Plain as the research area, and utilized a remote sensing interpretation and field visit method to analyze the land use situation during different periods of time. Also, the distribution scope of the natural grassland was identified, and the ecological security patterns of the agriculture and animal husbandry in the West Liaohe River Plain were adjusted based on the basic principle of natural grassland expansion. Then, the distribution of groundwater flow field in the research area was simulated, and the rationality of the ecological security pattern supported by the groundwater conditions was analyzed. The grassland areas after the adjustments measured $28,760.7 \mathrm{~km}^{2}$, and accounted for $43.87 \%$ of the total area of the West Liaohe River Plain. The grassland area will be recovered to the level of 1990 following the adjustment of this ecological pattern.
\end{abstract}

Keywords: land use, natural grassland, expansion, critical water levels, groundwater

\section{Introduction}

The breadth and depth of the influences of human activities on global ecosystems have been expanding continuously with the rapid progress of urbanization. Therefore, the structures and functions of natural ecosystems have significantly changed. The ecological environmental problems caused by the degradation of the ecological systems have become a bottleneck, and have restricted social and economic development. In the early 1980s, ecological security had become a research hotspot in the field of nascent international ecological systems (Naveh, 1994; Yu, 1996; Steffen et al., 2015), and as a result the ecological security pattern theory came into being at the right moment. On the basis of the mutual feedback between patterns and processes, it achieved effective control of the ecological process through the construction of regional ecological security patterns, in order to give full play to the ecological function; realize the effective and reasonable allocations of regional natural resources and green infrastructures; guarantee the necessary ecological natural resources and material welfare; and ultimately achieve ecological security (Dabelko, 1995; Peng et al., 2017). Ecological security patterns have become one of the important spatial methods used to alleviate the contradictions between ecological protection and economic development (Yu, 1996; Meng et al., 2012; Ou et al., 2015; Zhao and $\mathrm{Xu}, 2015)$. The majority of the hot spots include the farmingpastoral zones (Li and Cao, 2014), arid/semi-arid areas (Meng et al., 2017), scenic areas (Zhang et al., 2008). These types of areas are potentially strongly disturbed by human activities, resulting in the ecological safety problems becoming outstanding in these 
areas. Previously, many researchers have identified ecological sources based on a "source-sink" theory (Chen et al., 2006) of landscape ecologies, and established the resistance surfaces of the expansions of the landscape elements using minimum cumulative resistance models. The security patterns were then determined with different elements and classes according to the expansion trends (Pan and Liu, 2015), in order to effectively control the landscape space structure. In addition, cellular automata models (Zhu and Liu, 2013), scenario analyses (Mao et al., 2013), GAP analyses (Liu et al., 2009) were used for the establishment of the land ecological security patterns.

However, at the present time, the majority of the research studies conducted on the construction of the ecological security patterns have been analyzed from the perspective of landscape ecologies, without identifying the driving factors which had led to the changes of the regional ecological patterns. Also, the previous related studies also lacked evaluations of the effectiveness or rationality of the construction of the ecological security patterns based on the driving factors (Xu et al., 2017; Zhang et al., 2018). The natural attributes of the regional hydrological cycles determine the basic patterns of an ecosystem (Chen, 2007). For example, for semi-arid areas, the natural ecosystems are grassland vegetation supported by groundwater. The spatial patterns and landscape changes of ecosystems reflect the pattern evolution of the groundwater spatial distribution, and the realization of the ecological safety patterns must be supported by the groundwater conditions. For a long time, the agricultural structure in the farmingpastoral zones in semi-arid regions is unbalanced, with over-developed water sources, and the unsustainable problem in development is more and more serious. In part of the region, the development intensity of water source has approached extremity, with increasingly serious land desertification, grassland degradation and weakening ecological functions. Unbalance even reversal in ratio of plough and grassland has been a comparatively common phenomenon in farming-pastoral zones in semi-arid regions, which obviously does not conform to the national policy for ecological civilization construction, and it is required to research the agricultural and pastoral area ecological pattern that can guarantee ecological safety, and put forward the reasonable ratio for plough and grassland, which is an important ecological safety problem with farreaching influence. In this research study, by regarding the West Liaohe River Plain as the research area and based on a "source-sink" theory, a minimum cumulative resistance model was used to establish the landscape ecological security patterns. Also, the rationality of the ecological security pattern supported by the groundwater conditions was analyzed, in order to provide references for the ecological protection in semi-arid areas.

\section{Materials and methods}

In this research study, by taking the West Liaohe River Plain as an example, with the aim of protecting the natural attributes of the ecological system, a method was established for evaluating the ecological structure in the farming-pastoral zone, and a reasonable natural and human ecosystem was constructed. First, the remote sensing information and field visit data were used to analyze the changes in land usages in the West Liaohe River Plain, along with the distribution scope of the natural grassland. Second, the critical groundwater level of the vegetation community in the West Liaohe River Plain was calculated in combination with the data obtained from the field visit and historical investigations. Third, the existing natural grassland vegetation was found 
to have a good protection of biological diversity, and could be used as the gene pool for the ecological restoration of the grassland. Therefore, the outward expansion was based on the natural grassland in order to adjust and merge the grassland scope. Finally, the critical burying depth of the groundwater recharged vegetation was regarded as the constraint condition, in order to analyze the rationality of the ecological pattern supported by the groundwater subsurface flow field.

\section{Study areas}

In China, the semi-arid area is a strip zone between the arid area of the northwestern inland river, and the semi-humid area in the north and northeastern regions of China. This includes the west section of the Songliao River Basin; northwestern section of the Haihe-Luanhe River Basin; upper and middle reaches of the Yellow River Basin, and so on. Among these areas, the West Liaohe River was determined to be a relatively complete basin, and was therefore selected as the research area for this study (Fig. 1).

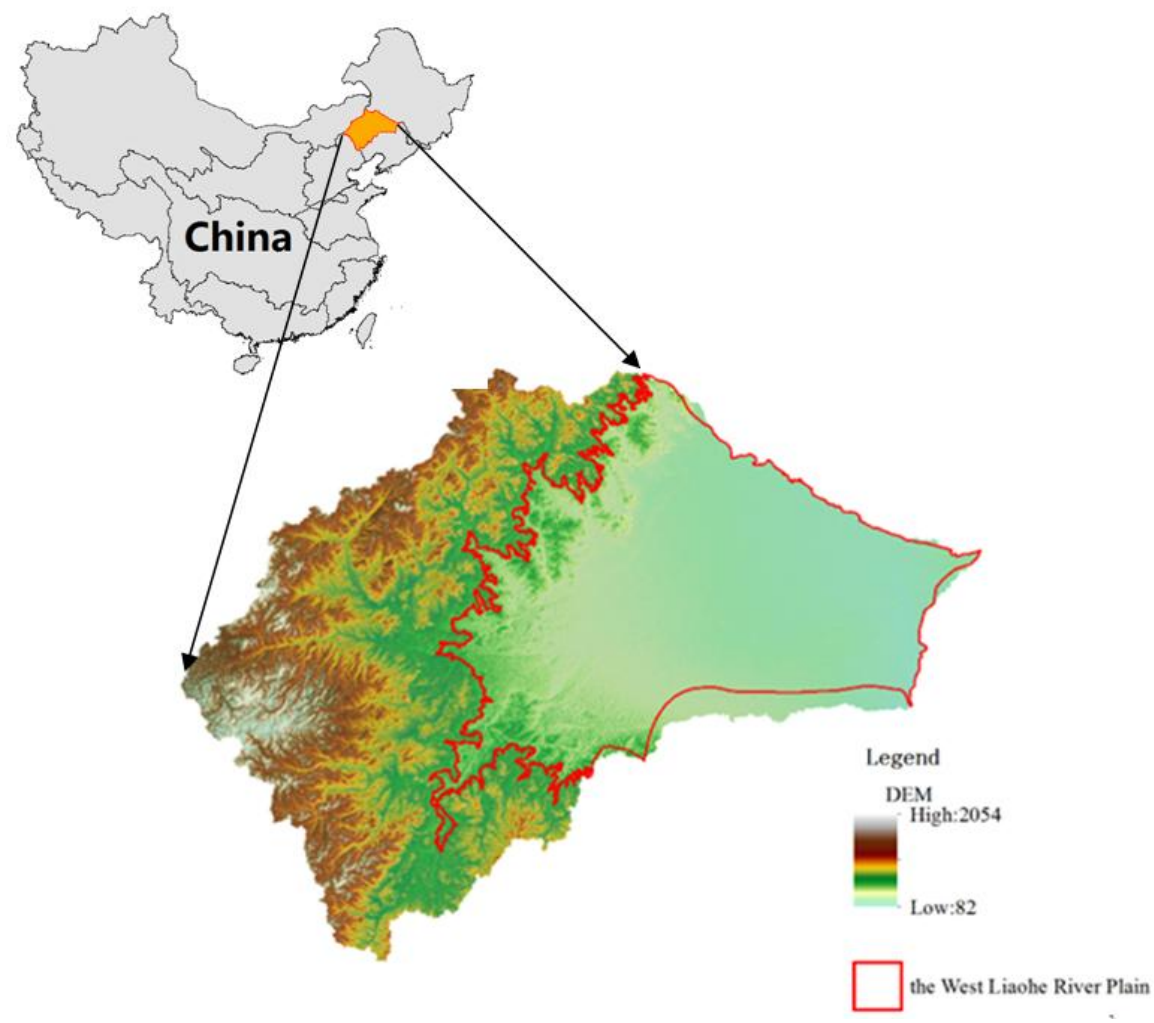

Figure 1. Study areas

The West Liaohe River Plain is located east of the West Liaohe River Basin. Its main section is located in Tongliao City, within $41^{\circ} 05^{\prime}$ to $45^{\circ} 13^{\prime} \mathrm{N}$ and $116^{\circ} 10^{\prime}$ to $123^{\circ} 35^{\prime} \mathrm{E}$, with a land area of approximately $65,000 \mathrm{~km}^{2}$. The West Liaohe River Plain is a typical farming-pastoral zone in the semi-arid region of China. The regional average annual precipitation is less than $380 \mathrm{~mm}$, and the annual average water evaporation is more than $1,000 \mathrm{~mm}$. Also, this area has obvious semi-arid characteristics. The rainfall in this area does not directly generate surface runoff, and the precipitation has a significant vertical infiltration. The groundwater is abundant, and the vertical recharge is stable. 
The vegetation in the pasturing area includes mainly typical herbaceous steppe vegetation communities, as well as arbor, shrub, and sub-shrub steppe vegetation and meadow vegetation communities. The natural ecology in a semi-arid area is a steppe vegetation supported by groundwater. The changes in the spatial patterns and landscapes of ecosystems are known to reflect the pattern evolution of the spatial distributions of the groundwater. The grassland ecologies represent the natural attributes of the ecosystems in semi-arid areas, and are the ecological foundations which support these areas. The grassland ecological security is not only related to the pasture itself, but also greatly affects the ecological quality, safety, and stability of the entire region.

\section{Changes in the land usages}

This study selected four periods for the interpretation of the land usage and analyzed the dynamic changes of the ecological patterns of the West Liaohe River Plain, in order to identify the distribution scope of the natural grassland in the West Liaohe River Plain, in combination with the field visit. The remote sensing interpretation results are shown in Figure 2.

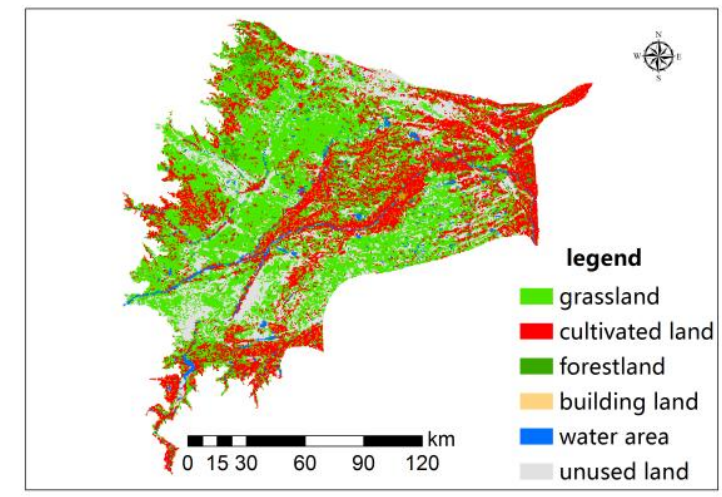

$\mathbf{a}$

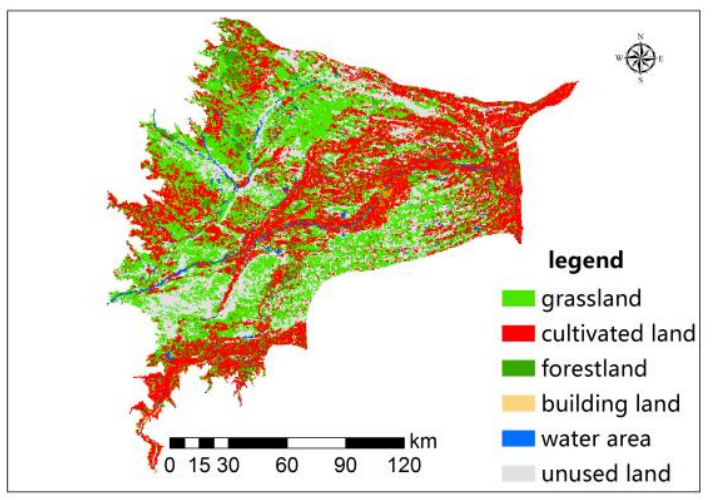

c

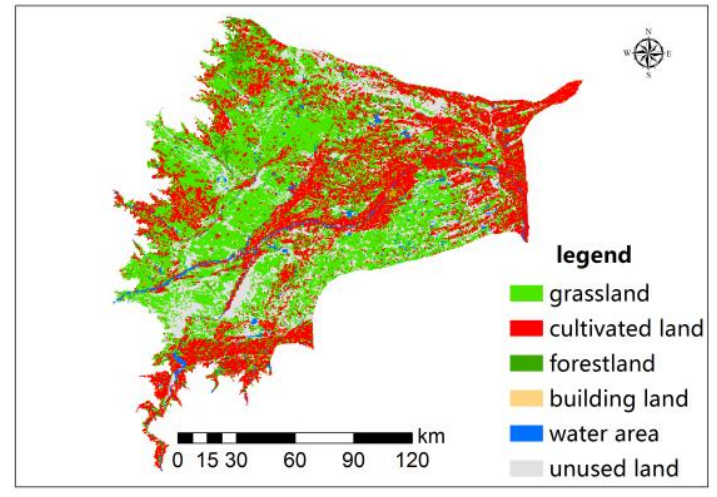

b

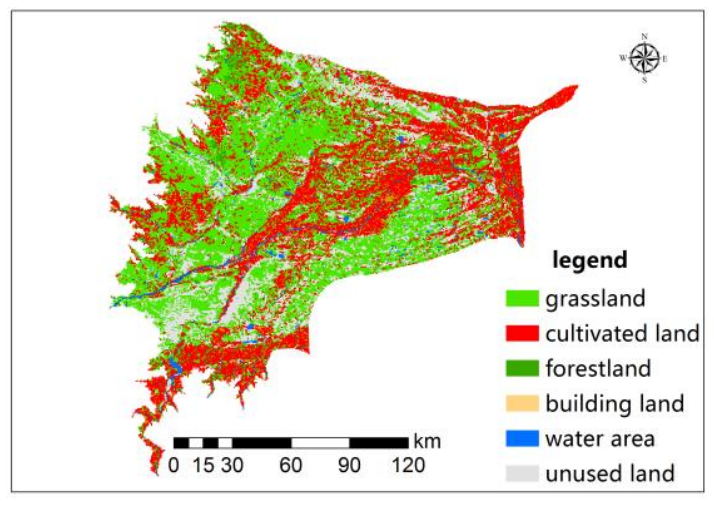

d

Figure 2. Distribution of the land use types in the West Liaohe River Plain between 1990 and 2016: $\boldsymbol{a} 1990, \boldsymbol{b} 2000, \boldsymbol{c} 2010$ and $\boldsymbol{d} 2016$

It was determined that, in the land use types of each region, the grassland and cultivated land areas occupied a larger proportion, while the water and construction land areas occupied a smaller proportion. The southwest, northeast, and middle areas were 
basically covered by cultivated land, while the grassland areas were mainly distributed in the Jarud Banner in the northwest, and Horqin Left Back Banner in the south. According to the comparison of the grassland and cultivated land areas during the different periods, the grassland area in the West Liaohe River Plain was found to have been sharply decreased, from $29,092 \mathrm{~km}^{2}$ in 1990 to $21,428 \mathrm{~km}^{2}$ in 2010 . Also, the grassland areas were increased after 2010, with the grassland areas reaching $22,439 \mathrm{~km}^{2}$ in 2016. The changes in the cultivated land areas showed an opposite trend. For example, the cultivated land areas increased from $18,251 \mathrm{~km}^{2}$ in 1990 to $26511 \mathrm{~km}^{2}$ in 2010. Moreover, the cultivated land areas had decreased after 2010, and were 23,372 $\mathrm{km}^{2}$ in 2016. It was found that the proportion of the agriculture and animal husbandry land usages in the West Liaohe River Plain had already been reversed by 2010.

\section{Grassland vegetation investigation}

The author carried out grassland vegetation investigation in grassland of West Liaohe River Plain for three times in July to August, 2016, and July to August, 2017 (Fig. 3), with vegetation investigation area of $6,702.89 \mathrm{~km}^{2}$, and 306 sampling points are selected in all. $94.1 \%$ of sampling points are concentrated in natural grassland, with 297 sampling points distributed in all; and 9 sampling points are spread in other regions. It can reflect the vegetation distribution condition of grassland in the West Liaohe River Plain basically, with good representativeness and comprehensiveness. Longitude and latitude positioning can be done for all the sampling points with handheld GPS, and the phytology professionals carry out statistics and record for the plant category and species name, perform photograph and description for the surrounding ecological environment of the sampling point, screen out the dominant species, and determine the community name and species composition of the sampling point.

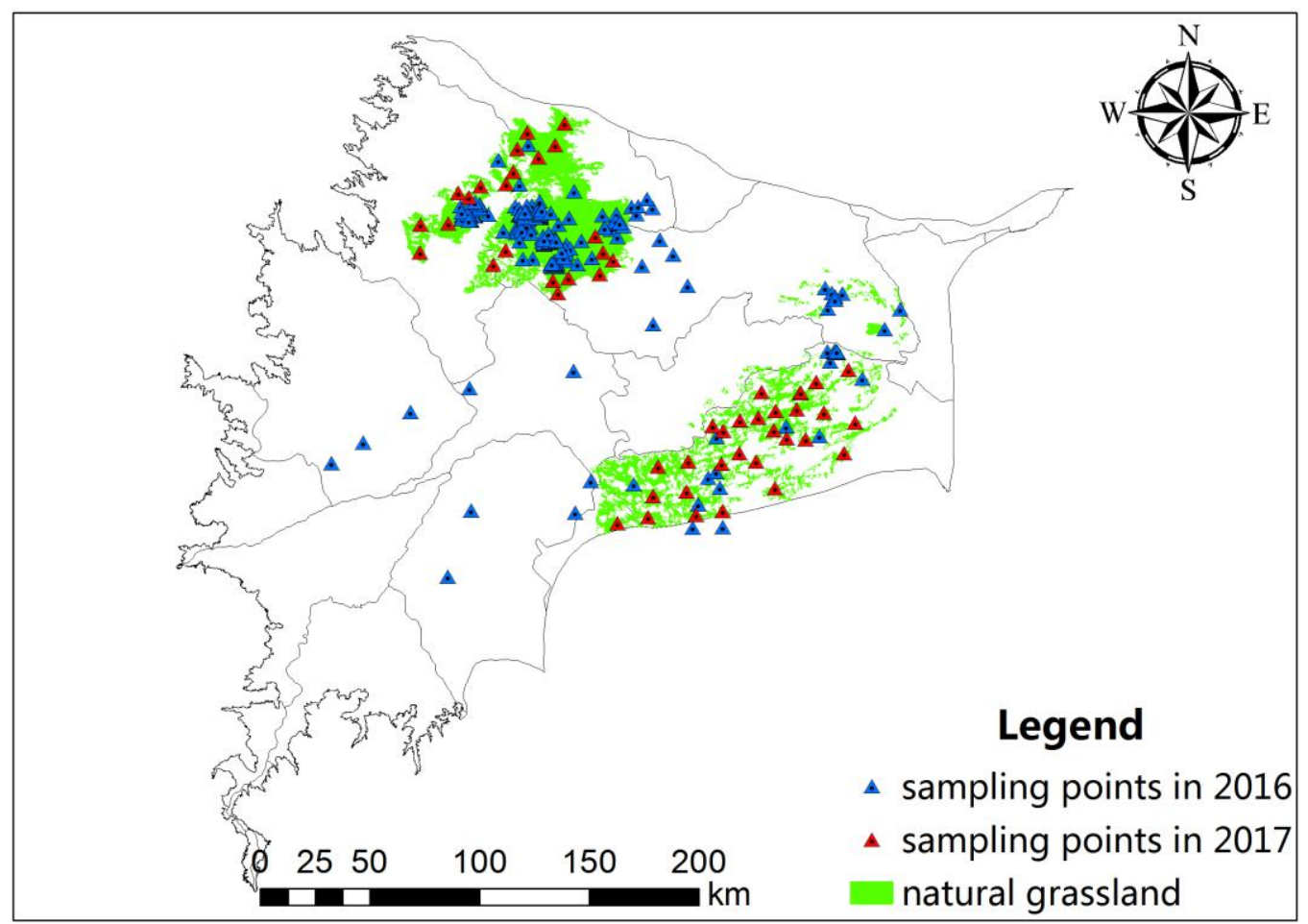

Figure 3. Sampling points of grassland vegetation investigation in West Liaohe River Plain 


\section{Calculation method for critical buried depth of groundwater recharge vegetation}

In regard to grassland plants in semi-arid areas, the ability of plants to absorb water is the most important condition for their competitive survival. Previously, many research studies have examined the adaptability rates of different plants under drought stress conditions (Zhou, 1999;Jin, 2010; Zhang, 2011). The author puts forward a kind of calculation method for critical buried depth of groundwater recharge vegetation (Chen et al., 2016). The analysis and calculation are composed of two parts: one is the vegetation root system active layer connected to ground, the other is the underwater diving active layer connected to groundwater surface. Under certain climate and soil condition, the root system layer thickness is related to vegetation type, which can be acquired according to the field investigation and the existing vegetation ecology research result. The forming of underwater diving active layer is the result of capillary force action, and the maximum lifting height of capillary water can be used as the thickness index of underwater diving active layer. Calculation formula for maximum lifting height $\mathrm{H}$ of capillary water is as follows:

$$
\mathrm{H}=2 \gamma / \rho \mathrm{R}
$$

$\rho$ is liquid density, $g$ is gravity acceleration, $R$ is effective aperture.

\section{Natural grassland expansion based on a source-sink theory}

In order to minimize the grassland degradation, the grain for green and closing measures have been widely applied in the farming-pastoral zones in recent years. The natural restorations of rehabilitated land areas are very slow processes. The formation of a stable vegetation community usually takes between 15 and 20 years. Moreover, the formations of such vegetation communities are relatively singular and do not contain rich species. Natural grasslands basically maintain the natural attributes of grassland areas due to good groundwater conditions, and less human interference. Natural grasslands have abundant plant species, and provide gene pools for grassland ecological restorations. Therefore, the adjustments in the ecological patterns in the farmingpastoral zone of the West Liaohe River Plain should include the expansion of the natural grassland as the basic principle, which will potentially increase the connectivity of the habitat patches and increase the mobility of the species among the patches. It will promote inter-plate gene exchanges and species mobility, as well as enhance the opportunities for species re-immigration. At the same time, the species in the isolated patches will be able to survive and continue, which will then provide a continuous network of habitats for the species which lack space diffusion capabilities. Therefore, the natural grassland areas will be continuously enlarged, and the natural nature of the natural grasslands can be maintained.

A "source-sink" theory is a basic theory which is used in the study of landscape ecology. The "source" landscape refers to the landscape type which can promote the development of the ecological processes in the study of the patterns and processes of an area. The "sink" landscape is the landscape type which can stop and delay the development of the ecological processes. The positive significance of the application of this theory was to couple the static landscape pattern with the dynamic ecological process. This assisted in the understanding of the relationship between the ecological pattern and the process, and provided a scientific basis for putting forward effective 
ecological spatial regulation and management methods. At the present time, this theory has been effectively applied on a large scale in the field of biodiversity conservation. Therefore, by taking the natural grassland expansion as the basic principle, this study used a "source-sink" theory method in the landscape ecology in order to adjust and optimize the ecological pattern of the agriculture and animal husbandry land usages in the West Liaohe River Plain. The natural grassland, as a gene pool for the grassland ecological restoration, played a key role in the safety of the entire plain ecosystem. Therefore, it was used as a "source" in this study, while the farmland and unused land were regarded as a "sink". In order to avoid direct conflicts among the different landscape functions (such as the grassland, farmland, and so on) from the aspect of a spatial pattern, a buffer zone was arranged in the contact zone between the grassland and large irrigation zone (including the closed grassland or artificial green belt) which eliminated the impact of the irrigation zone on the grassland, and facilitated the conservation and restoration of the natural attributes of the natural grassland areas.

In order to reflect the process in which the "source" landscape experienced different media in order to overcome resistance, it was necessary to evaluate the landscape resistance based on the dynamic characteristics of the "source" landscape in the study area. Therefore, with the help of GIS technology, this study used a minimum cumulative resistance model to express the influence of the landscape media on the spatial diffusion of the landscape "source", and thereby established a landscape resistance surface. The minimum cumulative resistance model considered the landscape "source", distance, and landscape interface characteristics, as shown in Equation 1:

$$
M C R=\mathrm{f} \min \sum\left(D_{\imath j} \times R_{i}\right)(\imath=1,2,3, \ldots m ; j=1,2,3, \ldots, n)
$$

where $D_{i j}$ refers to the field distance from the landscape "source" $\mathrm{j}$ to a landscape unit $\mathrm{i}$ in the space; and $R_{i}$ denotes to the resistance coefficient of a certain landscape unit $i$ in the space, and represents the difficulty level of the movement passing. The minimum cumulative resistance model used in this study was essentially the measurement and evaluation on the accessibility of a path from the "source" landscape to a point in the space. The smaller the resistance value, the higher the accessibility to this point. Therefore, the resistance model was able to reflect the potential possibility and tendency of the landscape unit movement, and was a type of abstract expression of the landscape changes. This provided an analysis basis for the landscape function characteristics. As far as the protection and utilization of the municipal ecosystem were concerned, the areas with stable municipal ecosystem structures were favorable to the migration and diffusion of the landscape unit, and the resistance to migration and diffusion were smaller. In contrast, there was a higher resistance to the unit movement and diffusion.

Different landscapes suffer different resistances during the processes of movement and migration, which are dependent on the suitability degree of the landscape interface to the survival, reproduction, and migration of the elements. However, the resistance coefficient is also relative, and can be used to calculate the cost distance since it can relatively reflect the differences in the different resistance factors. This research study set 1 as the minimum resistance coefficient, which represented the fact that a certain landscape unit could move freely, and its area was the most suitable space. Also, this study set 100 as the maximum resistance coefficient, which assumed that the landscape unit could not move, and its area was the most unsuitable space. As far as the research area was concerned, the areas which could not be adjusted involved urban development 
planning (such as urban construction land, large irrigation areas, and so), which were determined to have the largest resistance value (100). The farmland areas had a smaller resistance value of 70; unused land had a resistance value of 50; and the deteriorated grassland areas were given a resistance value of 10 .

The classified statistical measurements were made for the cumulative resistance values by using a $1 / 2$ standard derivation in GIS. The critical threshold was determined to divide the corresponding resistance intervals according to the frequency discontinuity and spatial distribution characteristics of the resistance value. Therefore, the influence degree of the natural grassland on the entire expandable area was divided into the expansion core area, expansion connection area, and expansion buffer area.

\section{Analysis of the rationality of the groundwater supported ecological pattern}

The natural grassland expansion areas had been adjusted to the different types of landscapes only from the perspective of landscape ecology. However, whether or not the groundwater conditions supported these adjustments of the ecological pattern still required verification. This study used a distributed type water cycle simulation model MODCYCLE as the tool (Lu et al., 2012), and simulated the groundwater flow field in the West Liaohe River Plain through establishing a water cycle simulation model for the West Liaohe River Basin. The period ranging from 2001 to 2014 was used as the base year period for the study of the West Liaohe River Basin. The hydrometeorological and water consumption data during the corresponding period were used as the basis to conduct the water cycle simulation construction, parameter calibration, and model validation in the base year of the West Liaohe River Plain area. The input data which were involved in the MODCYCLE model included the fundamental spatial data and the water cycle driving data. The spatial data included the basic region/basin information, such as the elevation, soil distribution, and so on, while the water cycle data included the meteorological driving data, water for human activities, and so on. This research study collected the meteorological data from 22 National Meteorological Stations in the West Liaohe River Plain, along with the precipitation data from 89 local rainfall stations (Fig. 4).

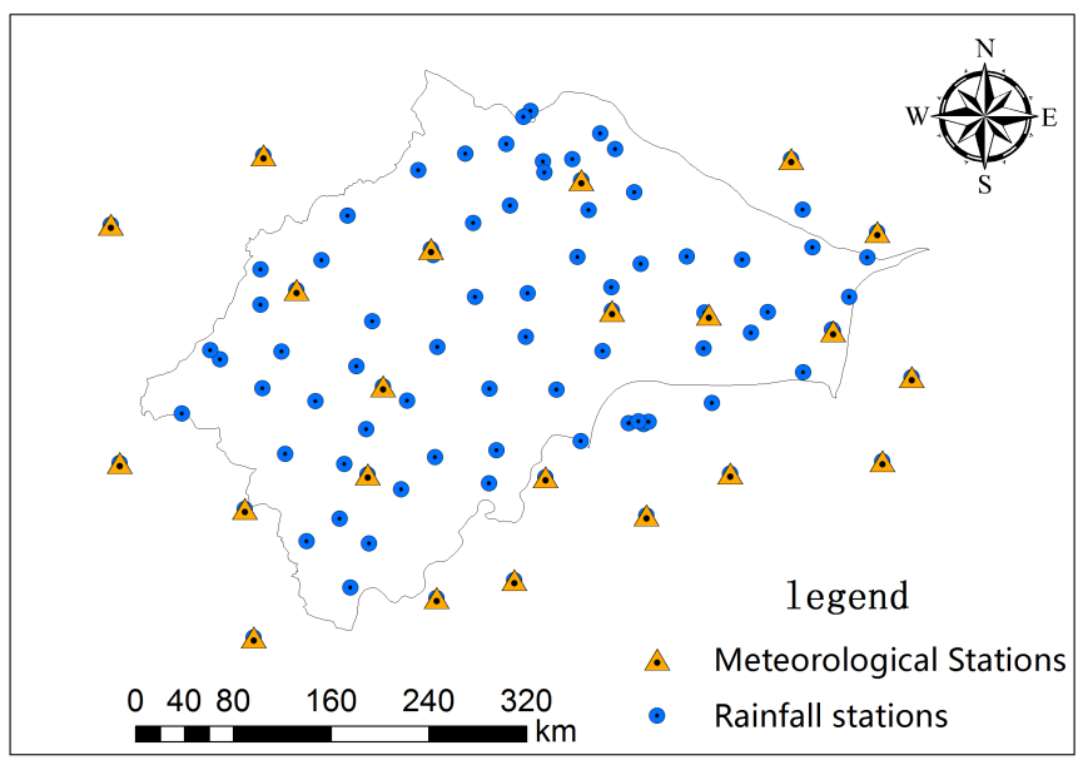

Figure 4. Distribution of national meteorological stations and rainfall stations 
The water intake and usage processes for human activities utilized the 2001 to 2014 statistical data from the water resources bulletin for the West Liaohe River Basin. Contour map for the groundwater depths in the West Liaohe River Plain in 2014 is shown in Figure 5.

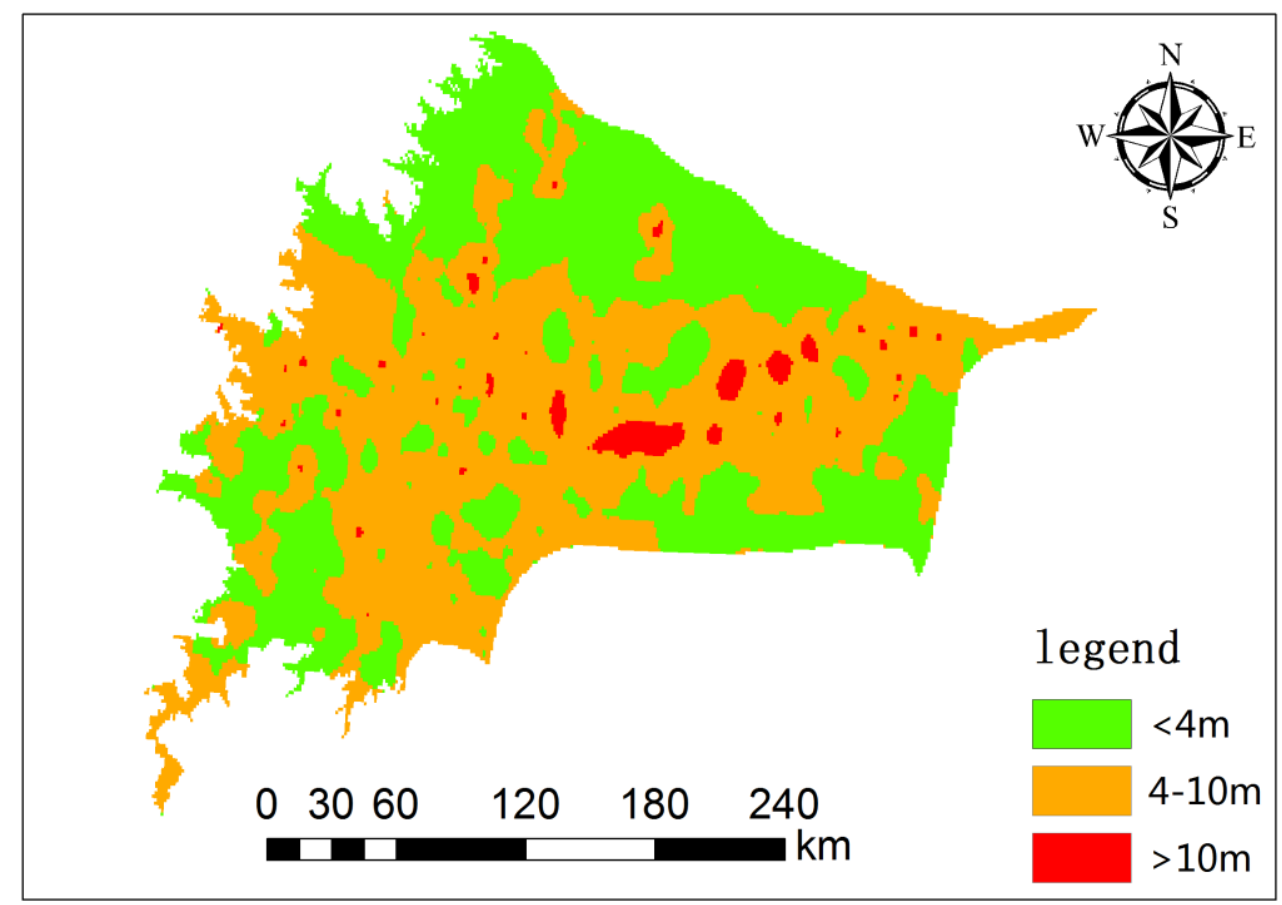

Figure 5. Contour map for the groundwater depths in the West Liaohe River Plain in 2014

The contour maps of the groundwater levels in the natural grassland expansion areas and the West Xiliao River Plain could be superposed. Then, the rationality of the ecological pattern of the farming and pastoral areas supported by the groundwater flow field were analyzed. The groundwater conditions in the expansion areas were divided into the supporting, basically supporting, and non-supporting areas according to the groundwater level values of $\leq 3 \mathrm{~m}, 3$ to $4 \mathrm{~m}$, and $>4 \mathrm{~m}$.

\section{Results and discussion}

\section{Distribution scope of natural grassland}

Through carrying out vegetation investigation of the West Liaohe River Plain, 306 valid sampling points are obtained, with 258 species of plants found in total, divided into 52 families and 169 categories. Grassland of the West Liaohe River Plain includes three types: natural grassland, sown pasture and deteriorated grassland (Fig. 6). Wherein, the natural grassland is influenced slightly by man-made interference, with rich vegetation species diversity and high vegetation coverage, and the grassland with natural property is the gene pool for grassland ecology restoration. The sown pastures in the West Liaohe River Plain are mainly planted with the commercial crop alfalfa, with high vegetation coverage but single composition. The deteriorated grassland is influenced by man-made interference intensely, and the vegetation composition is mainly successive 
vegetation, with low vegetation coverage. The grassland degraded seriously may be degraded to mobile sandy land, with exposed sand head and scare vegetation, and only the pioneer plants such as Agriphyllum arenariun Bieb. can grow here, which has lost the natural property of grassland basically. This paper interpreted the distribution condition and field vegetation investigation result of grassland with different coverages by using remote sensing, and recognized the distribution scope of grassland influenced by man-made interference slightly with natural property. The area of natural grassland is $6,702.89 \mathrm{~km}^{2}$, which is mainly distributed in Jarud Banner in northern part and Kezuohou Banner in southern part. Wherein, the natural grassland area of Jarud Banner is $3,932.43 \mathrm{~km}^{2}$, and that of the Kezuohou Banner is $2,770.46 \mathrm{~km}^{2}$.

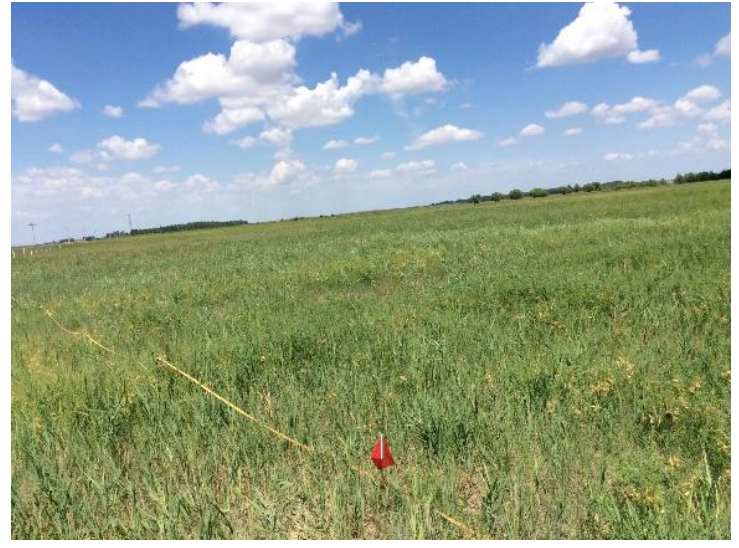

$\mathbf{a}$

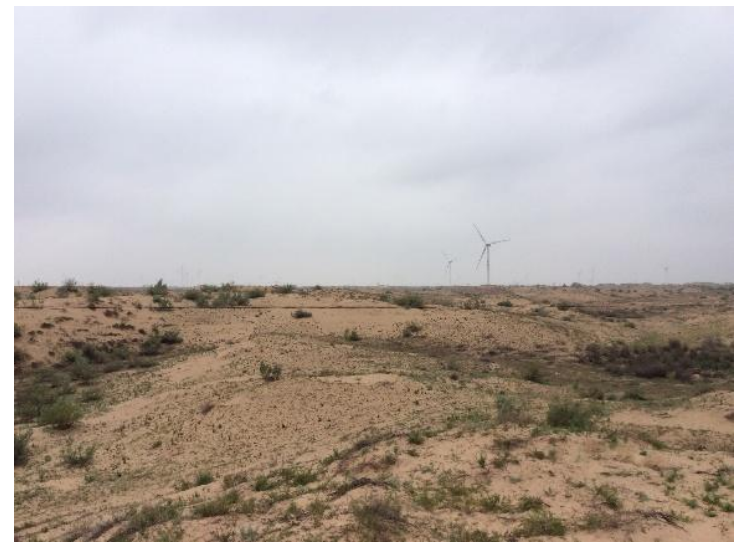

c

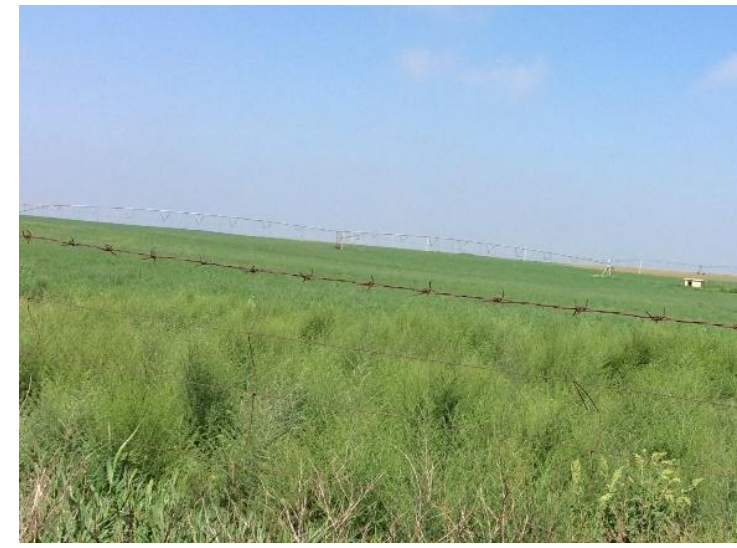

b

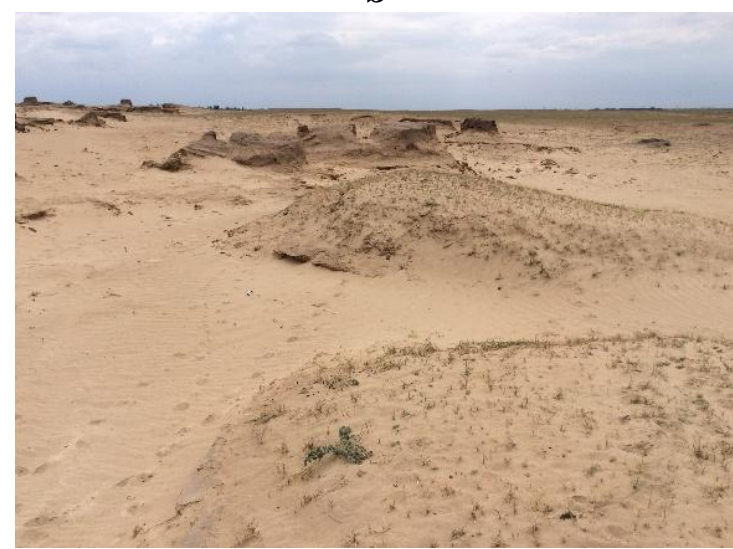

d

Figure 6. Types of grassland of the West Liaohe River Plain: a natural grassland, $\boldsymbol{b}$ sown pasture, $\boldsymbol{c}$ deteriorated grassland and $\boldsymbol{d}$ mobile sand land

\section{Critical water levels of the groundwater recharged vegetation}

Through the examination of the research data and vegetation investigation, and in accordance with the different water conditions, the steppe vegetation community in the West Liaohe River Plain was roughly divided into seven types and 22 communities. The critical burial depths of the groundwater of the different vegetation communities in the West Liaohe River Plain were obtained through calculation. The calculation results are shown in Table 1 as follows: the critical burial depths of the majority of the vegetation communities were within $4 \mathrm{~m}$. Meanwhile, the agriophyllum squarrosum community, 
which represented the pioneer community growing in the shifting sandy land areas, had root system lengths of up to $6 \mathrm{~m}$, and maximum critical burial depths of up to $7 \mathrm{~m}$.

Table 1. Critical water levels for the growth of the vegetation communities in the West Liaohe River Plain grassland areas

\begin{tabular}{c|c|c|c|c}
\hline Vegetation community & Soil type & $\begin{array}{c}\text { Capillary lift } \\
(\mathbf{m})\end{array}$ & $\begin{array}{c}\text { Root length } \\
(\mathbf{m})\end{array}$ & $\begin{array}{c}\text { Critical water level } \\
(\mathbf{m})\end{array}$ \\
\hline Typha orientalis Presl & Moisture soil & $0.5-1.0$ & 0.2 & In water \\
Scirpus validus Vahl & Moisture soil & $0.5-1.0$ & 0.15 & In water \\
Scirpus triqueter L. & Moisture soil & $0.5-1.0$ & 0.2 & 1.2 \\
Phragmites communis & Moisture soil & $0.5-1.0$ & 0.3 & 1.3 \\
Hemarthria altissima & Meadow soil & $0.5-1.0$ & 0.3 & 1.3 \\
Carex spp. & Meadow soil & $0.5-1.0$ & 0.3 & 1.3 \\
Agrostis alba L. & Meadow soil & $0.5-1.0$ & 0.3 & 1.3 \\
Sanguisorba officinalis L. & Meadow soil & $0.5-1.0$ & 0.3 & 1.3 \\
Potentilla anserine L. & Meadow soil & $0.5-1.0$ & 0.3 & 1.3 \\
Cyperus rotundus L. & Meadow soil & $0.5-1.0$ & 0.3 & 1.3 \\
Calamagrostis epigeios & Meadow soil & $0.5-1.0$ & 0.6 & 1.6 \\
Iris lactea & Meadow soil & $0.5-1.0$ & 0.8 & 1.8 \\
Suaeda glauca Bunge & Meadow soil & $0.5-1.0$ & 1.2 & 2.2 \\
Achnatherum splendens & Meadow soil & $0.5-1.0$ & 1.5 & 2.5 \\
Leymus chinensisTzvel. & Chestnut soil & 1.5 & 0.3 & 1.8 \\
Stipa grandis P. Smirn. & Chestnut soil & 1.5 & 0.5 & 2 \\
Cleistogenes squarrosa Keng & Chestnut soil & 1.5 & 0.6 & 2.1 \\
Artemisia frigida Willd. & Chestnut soil & 1.5 & 1 & 2.5 \\
Lespedeza bicolor Turcz & Chestnut soil & 1.5 & 1 & 2.5 \\
Artemisia halodendron & Sandy soil & $0.5-1.0$ & 1.5 & 2.5 \\
Caragana microphyllaLam & Sandy soil & $0.5-1.0$ & 3 & 4 \\
Agriophyllum squarrosum & Sandy soil & $0.5-1.0$ & 6 & 7 \\
\hline \multicolumn{2}{|r|}{}
\end{tabular}

\section{Distribution of the natural grassland expansion}

As detailed in Figure 7, The expansion core area of the natural grassland was determined to be $7,922 \mathrm{~km}^{2}$. It is distributed around the natural grassland, and suffered a lower level of resistance. Also, it played a key role in protecting the natural grassland from the interferences of human activities, thereby maintaining its natural attributes. It was considered to be the most direct area for the expansion of the natural grassland. The patches of farmland and unused land areas in this area were all completely adjusted to grassland. The farmland to grassland areas were implanted to the dominant and common associated species of the adjacent natural grassland plant communities through artificial cultivation or introduction processes.

The expansion connection areas of the natural grassland were determined to be $3,799.85 \mathrm{~km}^{2}$. With the outward expansion of the natural grassland along the expansion core area, it had suffered from major influences of human activities. This area showed a landscape pattern in which large sheets of deteriorated grasslands were staggered with patches of farmland and unused land. The differences between this area and the expansion core area were that the dominant species from the vegetation communities in 
the adjacent expansion core area had difficulties adapting when only the attributes of the patches were changed to those of closed grassland or further artificial planting. Therefore, in this study it was necessary to adjust the vegetation communities in the connected areas in combination with the aforementioned factors.

The expansion buffer areas of the natural grassland were determined to be 1859.51 $\mathrm{km}^{2}$. The larger the distance to the natural grassland resulted in higher resistance. The existing landscapes mainly included large irrigation areas, highly fragmented farmland areas near towns, unused land, and degraded grassland interlacing areas. These areas had a very low possibility of recovering the natural attributes of the natural grassland due to the limits imposed by urban development planning. This easily led to the loss of the natural attributes of the grassland under enhanced artificial interference conditions. Therefore, it was determined to be necessary to protect the patches in these areas and maintain stability by taking such measures as returning farmland to grassland, limiting land reclamation, closing degraded grassland, and so on. These measures provided security boundary conditions for the restoration of the grassland ecosystems within the core and connected regions of the study area.

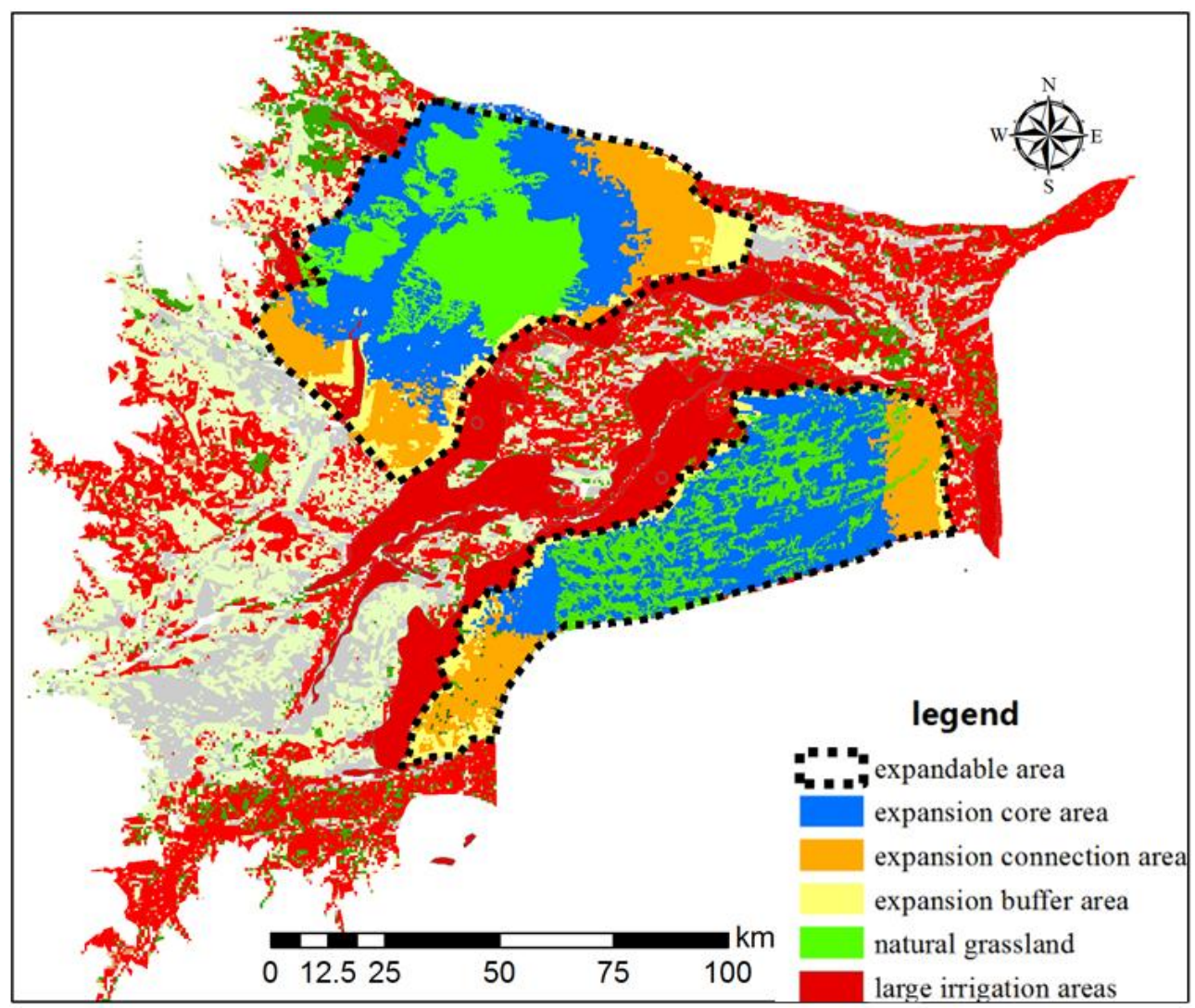

Figure 7. Distribution of the natural grassland expansion in the West Xiliao River Plain

\section{Ecological pattern}

As detailed in Figure 8, in the natural grassland expansion areas, the areas with groundwater levels within $3 \mathrm{~m}$ consisted of $5,258.96 \mathrm{~km}^{2}$. The groundwater conditions in these areas met the requirements to recharge water for the critical burial depths of the vegetation. Also, the adjustments of the ecological patterns in this area could be 
supported. The areas with groundwater levels within 3 to $4 \mathrm{~m}$ measured $4,565.86 \mathrm{~km}^{2}$, and the groundwater conditions in these areas had the ability to recharge water for the growth of fruticeta with long root systems, such as the dominant species Caragana microphylla Lam. The areas with ground water levels above $4 \mathrm{~m}$ accounted for $3,896.51 \mathrm{~km}^{2}$, and the ground water conditions in these areas were determined not to meet the recharging requirements of the critical burial depths of the vegetation. It was therefore concluded that the expansions of the natural grassland in these areas would be meaningless if the conditions of the groundwater were not improved. Therefore, the expansions of the natural grassland should first be transformed in the ecological pattern adjustment areas which were supported by the groundwater conditions. Second, shrub communities with long root systems, such as Caragana microphylla Lam, could be planted in the ecological pattern adjustment areas which were basically supported by the groundwater conditions. Finally, the ecological pattern adjustment areas which were not supported by the relative groundwater conditions could be eliminated.

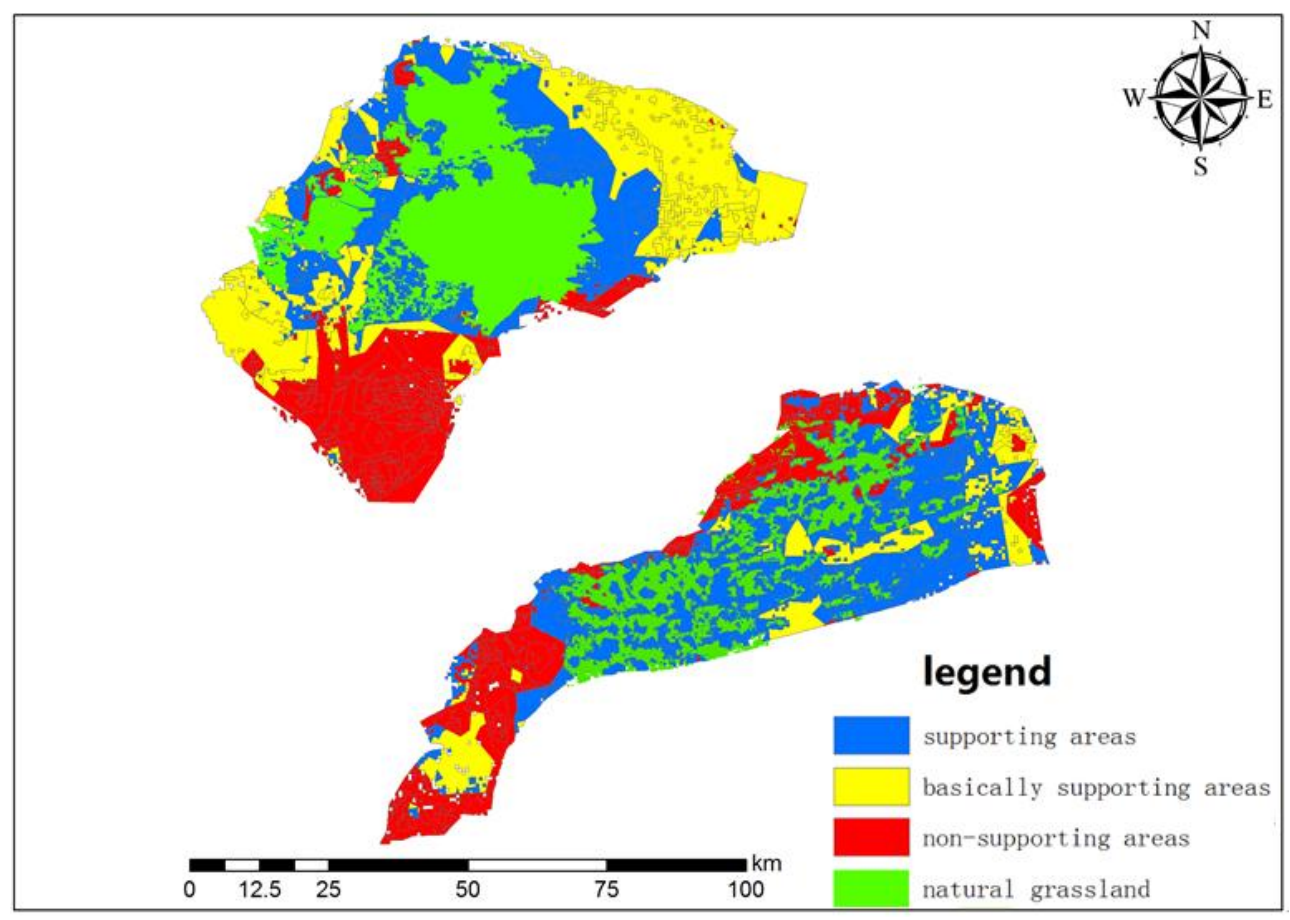

Figure 8. Distribution of the rationality of the ecological patterns supported by the groundwater subsurface flow field

The adjustments to the reasonable ecological patterns in the farming-pastoral zone of the West Liaohe River Plain were based on the basic principle of the natural grassland expansion. The optimization and adjustments of the ecological patterns were conducted using a landscape ecology method, and the demands of urban planning and socialeconomic development were also considered. Moreover, the groundwater conditions were used to analyze the rationality of the adjustments, and the results are shown in Figure 9. The grassland areas after the adjustments measured $28,760.7 \mathrm{~km}^{2}$, and accounted for $43.87 \%$ of the total area of the West Liaohe River Plain. Among the grassland areas, the natural grassland areas had been expanded by $8,909.24 \mathrm{~km}^{2}$, which increases from the original $6,702.89 \mathrm{~km}^{2}$ to $15,612.13 \mathrm{~km}^{2}$, which accounted for 
$23.87 \%$ of the total area of the West Liaohe River Plain. The farmland areas were determined to be $20,932.4 \mathrm{~km}^{2}$, which accounted for $31.93 \%$ of the total area of the West Liaohe River Plain. Among the farmland areas, the large irrigation areas were $7,729.58 \mathrm{~km}^{2}$, and accounted for $11.81 \%$ of the total area of the West Liaohe River Plain.

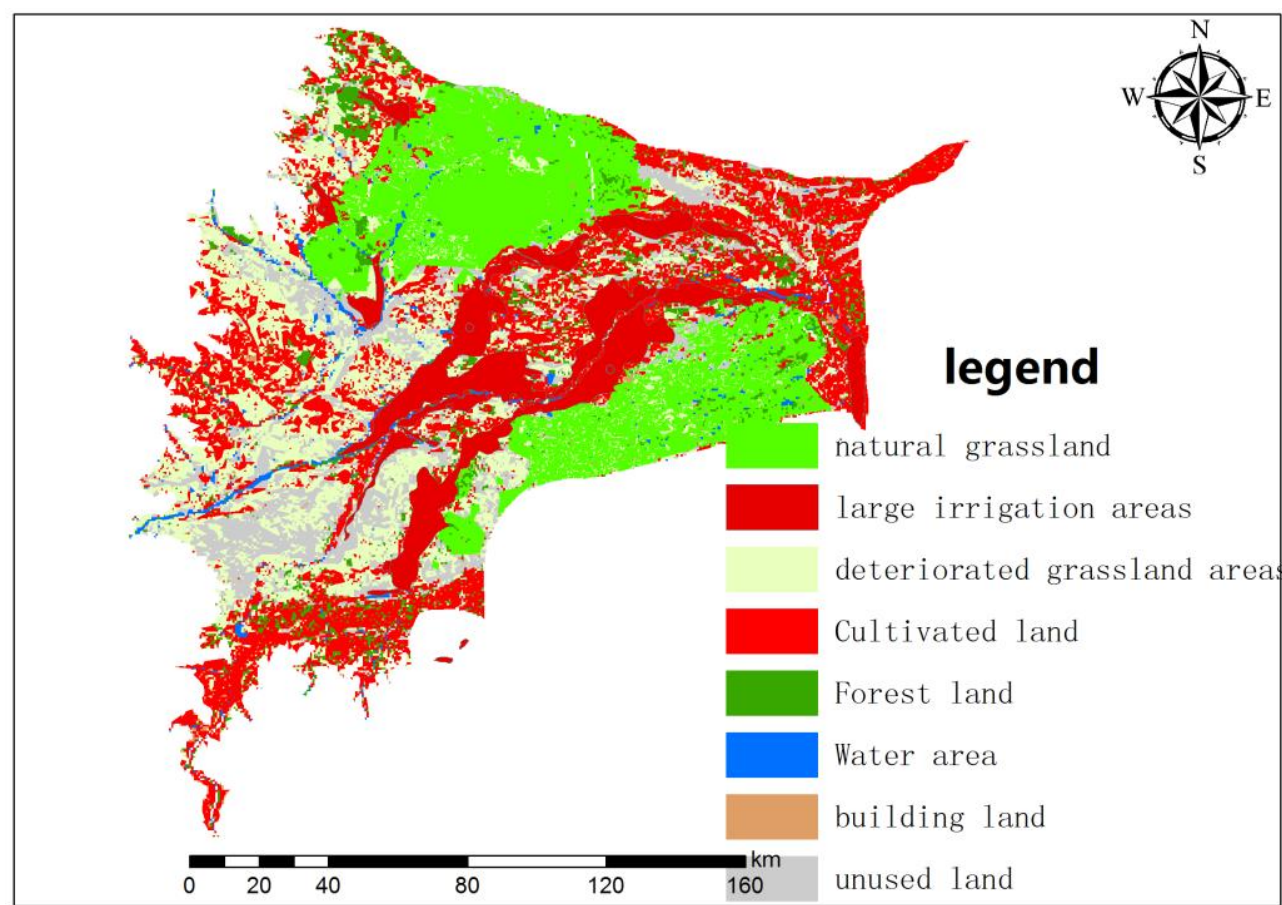

Figure 9. Ecological patterns of the farming-pastoral zone in the West Liaohe River Plain

Table 2 details the statistics of the land usage situations in the West Liaohe River Plain since 1990. Through this adjustment of the ecological pattern, the grassland areas have been basically recovered to the level of 1990, which has provided conditions for the ecological restoration of the grassland areas.

Table 2. Land usage situations in the West Liaohe River Plain during the different periods

\begin{tabular}{c|c|c|c|c|c}
\hline Land usage & $\left.\mathbf{1 9 9 0} \mathbf{( k m}^{2}\right)$ & $\left.\mathbf{2 0 0 0} \mathbf{( k m}^{2}\right)$ & $\left.\mathbf{2 0 1 0} \mathbf{( k m}^{2}\right)$ & $\left.\mathbf{2 0 1 6} \mathbf{( k m}^{2}\right)$ & Ecological pattern $\left.\mathbf{( k m}^{2}\right)$ \\
\hline Cultivated land & 18251 & 21215 & 26511 & 23372 & 20932.4 \\
Grassland & 29086 & 26640 & 21428 & 22439 & 28760.7 \\
Forest land & 2475 & 2950 & 2917 & 4296 & 4296 \\
Water area & 1876 & 1697 & 1564 & 1492 & 1492 \\
building land & 1616 & 1566 & 1665 & 1712 & 1712 \\
Unused land & 12257 & 11493 & 11476 & 12250 & 8367.9 \\
$\begin{array}{c}\text { Proportion of } \\
\text { cultivated land }\end{array}$ & $27.84 \%$ & $32.36 \%$ & $40.44 \%$ & $35.65 \%$ & $31.93 \%$ \\
$\begin{array}{c}\text { Proportion of } \\
\text { grassland }\end{array}$ & $44.36 \%$ & $40.63 \%$ & $32.68 \%$ & $34.23 \%$ & $43.87 \%$ \\
\hline
\end{tabular}




\section{Conclusion}

The farming-pastoral zones in semi-arid regions are typically ecologically fragile zones, as well as important ecological barriers. The ecological environments are not only the basis and guarantee of regional economic development, they are also barriers relating to the ecological security of the Yellow River Basin, Haihe River Basin, and Beijing-Tianjin-Hebei Regions. In this research study, by taking the West Liaohe River Plain as the research area, and the natural grassland expansion as the basic principle, adjustments were made to the ecological security patterns of the agriculture and animal husbandry in the West Liaohe River Plain. Then, the rationality of the ecological security patterns supported by the groundwater conditions was analyzed. The grassland areas were expanded through the adjustments of the ecological patterns, which provided the conditions and foundation for the ecological restoration of grassland. The natural attributes of the regional hydrological cycles determine the basic patterns of an ecosystem, it was necessary to recognize the decisive influences of the regulation and management of the groundwater level on the grassland vegetation community pattern. In future research, we should focus on how to improve the biodiversity of grassland and how to control the water level of the groundwater.

Acknowledgements. The research was supported by the ministry of water resources' special funds for scientific research on public (No.201501031) and the National Science Foundation for Distinguished Young Scholars of China (Grant No.51409271).

\section{REFERENCES}

[1] Chen, L., Fu, B., Zhao, W. (2006): Source-sink landscape theory and its ecological significance. - Frontiers of Biology in China 3(2): 131-136.

[2] Chen, M. J. (2007): Ecological effect of water cycling and classification of regional ecological water demand. - Journal of Hydraulic Engineering 38(3): 282-288.

[3] Chen, M. J., Zhang, Q. X., Ma, J., et al. (2016): Critical burial depth computing method for groundwater recharging vegetation. - CN 104751011 B. 2016. http://www.psssystem.gov.cn/sipopublicsearch/patentsearch/showViewListjumpToView. shtml

[4] Dabelko, G. D., Dabelko, D. D. (1995): Environmental security: Issues of conflict and redefinition. - Environmental Change and Security Project Report 1(1): 3-13.

[5] Jin, X. M. (2010): Quantitative relationship between the desert vegetation and groundwater depth in Ejina Oasis,the Heihe River Basin. - Earth Science Frontiers 17(6):181-186.

[6] Li, Y. B., Cao, C. (2014): Research for landscape ecological security pattern and early warning in farming-pastoral zone of northeast china: a case study off Tongyu County in Jilin Province. - Geography and Geo-Information Science 30(2): 111-115.

[7] Liu, J. P., Lv, X. G., Yang, Q., Wang, H. X. (2009): Wetland landscape ecological security patterns analysis and plan in Northeast of Sanjiang Plain. - Acta Ecologica Sinica 29(3): 1083-1090.

[8] Lu, C. Y. (2012): MODCYCLE - an object oriented modularized hydrological model I. Theory and development. - Shuili Xuebao 43(10): 1135-1145.

[9] Mao, X. Y., Meng, J. J., Xiang, Y. Y. (2013): CA-based model for developing land use ecological security pattern in semi-arid areas: a case study of Ordos, Inner Mongolia, China. - Environmental Earth Sciences 70(1): 269-279. 
[10] Meng, J. J., Wang, X. D., Zhou, Z. (2017): integrated landscape pattern optimization in arid region: a case study of middle reaches of Heihe River - Acta Scientiarum Naturalium Universitatis Pekinensis 53(3): 451-461.

[11] Meng, J. J., Zhu, L. K., Yang, Q. et al. (2012): Building ecological security pattern based on land use: A case study of Ordos, Northern China. - Acta Ecologica Sinica 32(21): 6755-6766.

[12] Naveh, Z. (1994): From biodiversity to ecodiversity: A landscape-ecology approach to conservation and restoration. - Restoration Ecology 2(3): 180-189.

[13] Ou, D. H., Xia, J. G., Zhang, L. et al. (2015): Research progress on regional ecological security pattern planning and discussion of planning technique flow. - Ecology and Environmental Sciences 24(1): 163-173.

[14] Pan, J. H., Liu, X. (2015): Assessment of landscape ecological security and optimization of landscape pattern based on spatial principal component analysis and resistance model in arid inland area: A case study of Ganzhou District, Zhangye City, Northwest China. Chinese Journal of Applied Ecology 26(10): 3126-3136.

[15] Peng, J., Zhao, H. J., Liu, Y. X., Wu, J. S. (2017): Research progress and prospect on regional ecological security pattern construction. - Geographical Research 36(3): 407419. DOI: $10.11821 /$ dlyj201703001.

[16] Steffen, W., Richardson, K., Rockström, J. et al. (2015): Planetary boundaries: Guiding human development on a changing planet. - Science 347(6223): 1259855.

[17] Xu, D. P., Li, T. S., Xue, X. J. et al. (2017): Research on sustainable development of different agricultural and pastoral land use patterns in northern farming-pasturing interlaced areas -taking Tongliao city of Inner Mongolia as an example. - Research of Soil and Water Conservation 24(1): 219-225.

[18] Yu, K. J. (1996): Security patterns and surface model in landscape ecological planning. Landscape and Urban Planning 36(1): 1-17.

[19] Zhang, Q. X., Chen, M. J. (2011): Eco-environmental problems caused by water resources development in Xiliao river watershed, China. - International Conference on Electrical and Control Engineering, 3447-3449. doi: 10.1109/ICECENG.2011.6058394

[20] Zhang, Y. H., Yu, C. Q., Tashpolat, T. et al. (2008): Methodology for constructing the landscape ecological security pattern in scenic area: A case study in the scenic area in the Miaofeng Mountain. - Arid Zone Research 25(3): 420-425.

[21] Zhang, Y. L., Li, X., Tian, Y. (2018): Study on ecological function zoning in the municipal administrative area based on the landscape ecology source-sink theory: a case study of Tongliao, Inner Mongolia. - Acta Ecologica Sinica 38(1): 65-72.

[22] Zhao, X. Q, Xu, X. H. (2015): Research on landscape ecological security pattern in a eucalyptus introduced region based on biodiversity conservation. - Russian Journal of Ecology 46(1): 59-70.

[23] Zhou, H. Y. (1999): Responses and variations of Artemisia frigida and Artemisia halodendron to water stress in Keerqin Sandyland. - Grassland of China (6): 13-17.

[24] Zhu, L., Liu, Y. X. (2013): Landscape optimization of typical oasis in Manas River Basin based on GIS and Cellular Automata. - Arid Land Geography 36(5): 946-954. 